\title{
BIOKIMIA DARAH TIKUS (RATTUS NORVEGICUS) BETINA OVARIEKTOMI SETELAH PERLAKUAN EKSTRAK DAUN KALIANDRA MERAH (Calliandra calothyrsus Meissn.)
}

\section{BLOOD BIOCHEMISTRY OF OVARIECTOMIZED FEMALE RAT (RATTUS NORVEGICUS) TREATED WITH RED CALLIANDRA (Calliandra calothyrsus Meissn.) LEAF EXTRACT}

\author{
Iriani Setyawati ${ }^{1 *}$, Ngurah Intan Wiratmini ${ }^{1}$, Ni Putu Ayu Dewi Wijayanti ${ }^{2}$ \\ ${ }^{1}$ Program Studi Biologi, ${ }^{2}$ Program Studi Farmasi, \\ Fakultas Matematika dan Ilmu Pengetahuan Alam, Universitas Udayana \\ Jl. Raya Kampus Bukit Jimbaran, Badung, Bali \\ *Email: iriani_setyawati@unud.ac.id
}

\begin{abstract}
INTISARI
Daun kaliandra merah (Calliandra calothyrsus Meissn.) memiliki potensi sebagai fitoestrogen. Pada penelitian ini, tikus betina dewasa ovariektomi sebagai model wanita menopause, diberikan ekstrak daun kaliandra yang mengandung flavonoid yang bersifat estrogenik. Penelitian ini merupakan metode eksperimental dengan Rancangan Acak Lengkap (RAL). Sebanyak 45 ekor tikus betina ovariektomi dibagi menjadi lima kelompok yaitu kontrol (K) yang tidak diberi perlakuan, serta kelompok perlakuan yang diberi ekstrak etanol $80 \%$ daun C. calothyrsus dosis $25 \mathrm{mg} / \mathrm{kg}$ bb (P1), dosis 50 $\mathrm{mg} / \mathrm{kg}$ bb (P2), $75 \mathrm{mg} / \mathrm{kg}$ bb (P3) dan $100 \mathrm{mg} / \mathrm{kg}$ bb (P4). Suspensi uji diberikan sekali sehari dengan interval 24 jam dengan metode gavage (cekok) sebanyak 0,5 ml/ekor/hari selama dua bulan. Di akhir perlakuan, dilakukan pengambilan darah untuk uji biokimia darah meliputi kadar hemoglobin, nilai hematokrit, kadar glukosa dan protein darah. Hasil penelitian menunjukkan bahwa ekstrak daun $C$. calothyrsus tidak berdampak negatif terhadap status kesehatan hewan coba melalui parameter biokimia darah yaitu kadar hemoglobin, nilai hematokrit, serta kadar glukosa dan protein darah tikus betina ovariektomi.
\end{abstract}

Kata kunci: Calliandra calothyrsus, ovariektomi, hemoglobin, hematokrit, glukosa darah, protein darah

\section{ABSTRACT}

Red calliandra (Calliandra calothyrsus Meissn.) leaf have the potential as phytoestrogens. In this study, adult female ovariectomized rats (as a model of menopause women) were given calliandra leaf extract containing estrogenic flavonoids. This study was an experimental design with a Completely Randomized Design (CRD). Forty-five ovariectomized female rats were divided into five groups i.e. untreated control (K), and the treatment group given $80 \%$ of C. calothyrsus ethanolic leaves extract doses $25 \mathrm{mg} / \mathrm{kg}$ bw (P1), $50 \mathrm{mg} / \mathrm{kg}$ bw (P2), $75 \mathrm{mg} / \mathrm{kg}$ bw (P3) and $100 \mathrm{mg} / \mathrm{kg}$ bw (P4). The test suspension was given once a day at 24-hour intervals by gavage as much as $0.5 \mathrm{ml} / \mathrm{rat} / \mathrm{day}$ for two months. At the end of the treatments, blood was collected for blood biochemical tests including hemoglobin levels, hematocrit values, blood glucose and proteins levels. The results showed that $C$. calothyrsus leaf extract did not negatively affect the health status of the animals through blood biochemical parameters, i.e. hemoglobin levels, hematocrit values, and glucose and protein levels of ovariectomized female rats.

Keywords: Calliandra calothyrsus, ovariectomy, hemoglobine, hematocrit, blood glucose, blood protein

\section{PENDAHULUAN}

Dewasa ini, penelitian untuk mengeksplorasi sumber-sumber estrogen eksogen (dari luar tubuh) yang relatif aman telah dilakukan sebagai pengganti estrogen endogen. Telah diketahui terdapat senyawa-senyawa dari tumbuhan bersifat estrogenik (dikenal sebagai fitoestrogen) yaitu senyawa flavon, isoflavon dan derivat kumestan (Tanu, 2005). Berdasarkan kandungan kimianya, daun kaliandra merah (Calliandra calothyrsus Meissn.) memiliki potensi sebagai fitoestrogen. Daun kaliandra diketahui mengandung berbagai senyawa, antara lain flavonoid, quercetin, saponin, asam kafeat, dan alkaloid (Moharram et al., 2006; Onyeama et al., 2012; Orishadipe et al., 2010).

Hingga saat ini belum ada penelitian terhadap potensi tanaman kaliandra sebagai sumber fitoestrogen. Pada penelitian ini, tikus betina dewasa yang telah dihilangkan ovariumnya melalui operasi ovariektomi sebagai model wanita menopause, diberikan ekstrak daun kaliandra yang mengandung flavonoid yang bersifat estrogenik. Penelitian ini bertujuan untuk mengetahui status kesehatan tikus betina dewasa ovariektomi yang diberikan ekstrak daun kaliandra melalui parameter hematologi dan biokimia darah.
Darah merupakan salah satu cairan tubuh yang peredarannya mengalir ke seluruh bagian tubuh (Murray et al., 2003). Komponen hematologi dan biokimia darah sangat dipengaruhi oleh kuantitas dan kualitas nutrisi yang terdapat di dalam makanan. Komponen biokimia darah sangat sensitif terhadap elemen toksisitas yang terkandung di dalam makanan, sedangkan komponen hematologi darah dapat memonitor toksisitas makanan, khususnya berbagai konstituen nutrien yang berpengaruh terhadap pembentukan darah (Ahamefule et al., 2006). Apabila terjadi penyimpangan status fisiologi individu, maka komponen dan sifat darah akan mengalami perubahan. Sebaliknya, jika nilai tersebut dalam batas normal maka metabolisme, pertumbuhan serta ketahanan tubuh masih dalam kondisi baik.

\section{BAHAN DAN METODE}

\section{Ekstraksi daun kaliandra}

Daun Calliandra calothyrsus yang berwarna hijau tua segar diperoleh dari kawasan Baturiti, Bedugul, Kabupaten Tabanan. Daun dikeringkan dengan cara diangin-anginkan kemudian diblender hingga menjadi serbuk. Serbuk daun Calliandra calothyrsus 500 g 
dimaserasi dengan $2500 \mathrm{~mL} n$-heksana pada suhu kamar selama satu hari, lalu disaring. Ampasnya dimaserasi kembali menggunakan $2500 \mathrm{~mL} n$-heksana dengan 2 kali pengulangan. Ampas didigesti dengan pelarut etanol $80 \%$ sebanyak $2500 \mathrm{~mL}$ selama 2 jam, lalu maserat disaring. Ampas didigesti kembali dengan 2 kali pengulangan selama masing-masing 2 jam. Maserat yang diperoleh melalui penyaringan dimasukkan ke dalam wadah, lalu diproses menggunakan vaccum rotary evaporator suhu $50^{\circ} \mathrm{C}$, selanjutnya dioven pada temperatur $40^{\circ} \mathrm{C}$.

\section{Persiapan hewan coba}

Hewan coba yang digunakan dalah tikus putih (Rattus norvegicus) betina dewasa sebanyak 45 ekor. Tikus diadaptasi selama 2 minggu dan diberikan pakan standar (pelet ABS) serta minum aqua isi ulang secara $a d$ libitum. Tikus kemudian dipingsankan dan dibedah untuk operasi pengangkatan ovarium (ovariektomi) sebagai hewan model wanita menopause. Setelah ovariektomi, tikus diadaptasi 2 minggu untuk pemulihan kondisi pasca operasi.

Hewan dipelihara dalam kandang yang terbuat dari plastik berukuran 30x20x12 cm, yang dilengkapi kawat kasa penutup pada bagian atasnya, dasar kandang dialasi dengan sekam untuk menyerap urin dan feses. Tikus dipelihara pada suhu ruang $\left( \pm 27^{\circ} \mathrm{C}\right)$, dengan kelembaban relatif sekitar $60 \%$, dengan pencahayaan 12:12 jam (terang : gelap). Tikus ditimbang bobot badannya sebagai dasar penentuan volume suspensi perlakuan. Sebelum penelitian, dilakukan penentuan ethical clearance terhadap hewan coba oleh Komisi Bioetik untuk Hewan Coba, FKH Universitas Udayana.

\section{Perlakuan Ekstrak terhadap Tikus Betina Ovariektomi}

Empat puluh lima ekor tikus betina ovariektomi dibagi menjadi lima kelompok yaitu kontrol (K) yang tidak diberi perlakuan, serta kelompok perlakuan yang diberi ekstrak etanol $80 \%$ daun C. calothyrsus dosis $25 \mathrm{mg} / \mathrm{kg}$ bb (P1), dosis $50 \mathrm{mg} / \mathrm{kg}$ bb (P2), $75 \mathrm{mg} / \mathrm{kg}$ bb (P3) dan 100 $\mathrm{mg} / \mathrm{kg}$ bb (P4). Suspensi uji diberikan sekali sehari dengan interval 24 jam dengan metode gavage (cekok) menggunakan sonde setiap sore hari dimulai sebanyak 0,5 $\mathrm{ml} /$ ekor/hari selama dua bulan. Di akhir perlakuan, tikus betina dikorbankan dengan injeksi ketamine intramuskular pada paha belakang untuk pengambilan sampel darah serta organ.

\section{Analisis biokimia darah}

Setelah dibius, darah tikus diambil dari jantung menggunakan spuit $1 \mathrm{ml}$ dan dipindahkan ke dalam tabung berisi heparin supaya tidak terjadi pembekuan. Darah disentrifugasi dengan kecepatan 1200 rpm (10 menit), plasma darah kemudian dimasukan ke dalam ependorf.

Kadar hemoglobin ditentukan dengan metode hematin-asam dengan hemometer Sahli, kadar $\mathrm{Hb}$ ditetapkan dalam g/dL. Nilai hematokrit ditentukan dengan menggunakan metode mikrohematokrit. Dibaca tinggi kolom eritrosit dengan alat pembaca hematokrit dan nilainya dinyatakan dalam \% (Brown, 1980).

\section{Analisis data}

Analisis statistik dilakukan dengan program SPSS versi 22 (IBM). Uji statistik deskriptif, uji normalitas data (Kolmogorov-Smirnov test), serta uji One Way Anova dengan uji lanjut Duncan.

\section{HASIL DAN PEMBAHASAN}

Hasil analisis statistik data tentang status kesehatan tikus betina ovariektomi yang dikaji melalui parameter biokimia darah yang meliputi kadar hemoglobin dan nilai hematokrit serta kadar glukosa dan protein darah disajikan pada Tabel 1.

Tabel 1. Kadar Hemoglobin, Hematokrit, Glukosa dan Protein Darah Tikus Betina Ovariektomi

\begin{tabular}{lcccc}
\hline \multicolumn{1}{c}{ Perlakuan } & $\begin{array}{c}\text { Hemoglobin } \\
(\mathrm{g} / \mathrm{dl})\end{array}$ & $\begin{array}{c}\text { Hematokrit } \\
(\%)\end{array}$ & $\begin{array}{c}\text { Glukosa darah } \\
(\mathrm{mg} / \mathrm{dl})\end{array}$ & $\begin{array}{c}\text { Protein darah } \\
(\mathrm{g} / \mathrm{dl})\end{array}$ \\
\hline Kontrol & $13,20 \pm 0,400 \mathrm{a}$ & $51,50 \pm 2,082 \mathrm{a}$ & $112,75 \pm 0,046 \mathrm{a}$ & $4,70 \pm 0,490 \mathrm{a}$ \\
P1 $(25 \mathrm{mg} / \mathrm{kg} \mathrm{bb})$ & $13,15 \pm 0,192 \mathrm{a}$ & $51,25 \pm 2,217 \mathrm{a}$ & $110,50 \pm 7,506 \mathrm{a}$ & $6,50 \pm 0,913 \mathrm{a}$ \\
P2 $(50 \mathrm{mg} / \mathrm{kg} \mathrm{bb})$ & $13,05 \pm 0,100 \mathrm{a}$ & $51,25 \pm 1,708 \mathrm{a}$ & $114,50 \pm 4,203 \mathrm{a}$ & $4,85 \pm 0,819 \mathrm{a}$ \\
P3 $(75 \mathrm{mg} / \mathrm{kg} \mathrm{bb})$ & $13,10 \pm 0,841 \mathrm{a}$ & $49,50 \pm 2,646 \mathrm{a}$ & $104,75 \pm 6,397 \mathrm{a}$ & $5,48 \pm 2,142 \mathrm{a}$ \\
P4 $(100 \mathrm{mg} / \mathrm{kg}$ bb) & $13,20 \pm 0,400 \mathrm{a}$ & $50,50 \pm 1,291 \mathrm{a}$ & $111,50 \pm 6,658 \mathrm{a}$ & $6,65 \pm 2,249 \mathrm{a}$ \\
\hline
\end{tabular}

Huruf yang sama mengikuti nilai (Mean \pm SD) pada kolom yang sama menunjukkan perbedaan non signifikan $(\mathrm{P}>0,05)$

Kelemahan kaliandra adalah efek antinutrisinya akibat tingginya kadar condensed tannin (CT), pada Calliandra calothyrsus Meissn $>10 \%$. Tanin dapat mengikat protein dalam makanan sehingga protein sulit tercerna dan lolos bersama feses. Tanin juga dapat mengikat karbohidrat termasuk polisakarida dan selulosa, enzim-enzim pencernaan serta mineral.

Menurut Ashok dan Upadhyaya (2012), komponen dan level tanin cenderung menunjukkan pengaruh yang bervariasi terhadap konstituen darah. Tanin dilaporkan dapat mengganggu penyerapan zat besi, padahal zat besi sangat vital dalam pengikatan oksigen oleh hemoglobin di dalam sel darah merah. Hal ini dapat mempengaruhi kadar hemoglobin dan nilai hematokrit darah. Namun demikian di dalam penelitian ini, status kesehatan tikus betina ovariektomi tetap baik, ditunjukkan dengan nilai kadar hemoglobin dan nilai hematokrit tikus yang tidak berbeda signifikan antara kontrol dengan perlakuan ekstrak daun C. calothyrsus.

Kadar glukosa darah tikus betina ovariektomi tidak menunjukkan perubahan yang signifikan setelah perlakuan ekstrak daun $C$. calothyrsus, dengan nilai rataan kadar glukosa darah yang tidak berbeda nyata antara semua perlakuan dengan kontrol (Tabel 1). Kadar glukosa darah adalah perimbangan sesaat antara laju terserapnya glukosa dari saluran digestif ke sirkulasi, serta laju glukosa dari sirkulasi darah ke sel-sel tubuh pada saat berlangsungnya metabolisme karbohidrat (Aslamyah, 2006).

Ekstrak daun kaliandra diketahui mengandung senyawa polifenol. Polifenol dapat mempengaruhi 
metabolisme glukosa dengan menstimulasi pengambilan glukosa perifer pada jaringan yang sensitif maupun non sensitif terhadap insulin (Zaid et al., 2008). Beberapa penelitian menemukan bahwa beberapa asam fenolat dari golongan polifenol telah terbukti menghambat transport glukosa. Asam klorogenat, asam ferulat, asam kafeat, asam tanat, kuercetin monoglukosida, katekin teh, dan naringenin adalah kelompok polifenol yang menghambat transpor glukosa yang diperantarai oleh ion $\mathrm{Na}^{+}$ bergantung $\mathrm{SGLT}_{1}$. Sedangkan transport glukosa oleh GLUT $_{2}$ dihambat oleh kelompok polifenol lainnya yaitu kuercetin, myricetin, apigenin dan katekin teh (Hanhineva et al., 2010). Dengan terhambatnya transpor glukosa oleh senyawa polifenol tersebut, terhambat juga absorpsi glukosa oleh usus halus untuk ditranspor ke dalam darah sehingga kadar glukosa darah turun.

Tanin mungkin memiliki efek untuk menurunkan kadar glukosa darah pada tikus (Bennick, 2002), namun hal ini tidak terjadi dalam penelitian ini. Pada tikus, batas normal kadar glukosa darah berkisar 50-135 mg/dL (Delaney, 1996). Kadar glukosa darah seluruh tikus pada akhir penelitian ini masih dalam batasan normal yaitu 104,75-114,50 mg/dL.

Kadar protein darah tikus betina ovariektomi juga tidak menunjukkan perubahan yang signifkan dengan perlakuan ekstrak daun C. calothyrsus, ditunjukkan dengan nilai rataan kadar total protein darah antara perlakuan dengan kontrol tidak berbeda nyata (Tabel 1). Protein darah berperan sebagai sumber nutrien bagi jaringan, menjaga tekanan dan $\mathrm{pH}$ darah. Selain itu didapatkan juga protein lain dalam darah diantaranya hormon, enzim dan faktor pembeku darah (Frandson, 1992).

Protein yang dikonsumsi dapat mempengaruhi distribusi asam amino di dalam darah (Guyton dan Hall, 2007), dengan demikian interaksi tanin kaliandra dengan protein juga dapat mempengaruhi profil protein darah. Perubahan ini tidak terjadi dalam penelitian ini. Pada tikus, kadar normal total protein darah berkisar 5,6-7,6 g/dL (Delaney, 1996), sedangkan kisaran kadar total protein darah tikus dalam penelitian ini masih dalam kisaran 4,70$6,65 \mathrm{~g} / \mathrm{dL}$.

Riset-riset terus mengevaluasi efek biologis fitoestrogen terhadap kesehatan manusia, kompleksitasnya makin nyata melalui kajian efek estrogenik dan antiestrogenik serta mekanisme aksi fitoestrogen (Kronenberg dan Hughes, 1999). Berdasarkan hasil pengujian biokimia darah yang tetap tidak berubah dan tidak berbeda nyata dengan kontrol, membuktikan bahwa perlakuan ekstrak daun kaliandra tidak mempengaruhi status kesehatan tikus betina ovariektomi sehingga dapat dilanjutkan untuk lebih jauh mengkaji potensi fitoestrogen esktrak ini terhadap tikus betina ovariektomi (model wanita menopause).

\section{KESIMPULAN}

Ekstrak daun Calliandra calothyrsus tidak berdampak negatif terhadap status kesehatan melalui parameter biokimia darah yaitu kadar hemoglobin, nilai hematokrit, serta kadar glukosa dan protein darah tikus betina ovariektomi.
Ashok, P.K. and Upadhyaya, K. 2012. Tannins are Astringent. Journal of Pharmacognosy and Phytochemistry 1(3): 45-50.

Aslamyah, S. 2006. Penggunaan Mikroflora Saluran Pencernaan Sebagai Probiotik Untuk Meningkatkan Pertumbuhan Dan Kelangsungan Hidup Ikan Bandeng (Chanos chanos Forsskal) (disertasi), Bogor, Sekolah Pascasarjana IPB.

Bennick, A. 2002. Interaction of Plant Polyphenols with Salivary Proteins. Critical Rewiews in Oral Biology and Medicine 13(2): 184-196.

Delaney, J.C. 1996. Exotic Animal Companion, Medicine Handbook for Veterinarians, Zoological Education Network.

Frandson, R. D. 1992. Anatomy and Phisiology of Farm Animals. Lippincot Williams and Wilkins. A Wolters Kluwer Company. Philadelphia.

Guyton, A.C. and Hall, J.E. 2007. Fisiologi Kedokteran. Penterjemah Luqman Yanuar R, Editor Irawati. Terjemahan dari Textbook of Medical Physiology. Jakarta: EGC.

Hanhineva, K., Torronen, R., Bondia-Pons, I., Pekkinen, J., Kolehmainen, M., Mykkanen, H. and Poutanen, K. 2010. Impact of Dietary Polyphenols on Carbohydrate Metabolism. Int. J. Mol. Sci. 11: 13651402.

Moharram, F.A., M.S.A., Marzouk, M.T., Ibrahim, and T.J., Marby. 2006. Antioxidant Galloylated Flavanol Glycosides from Calliandra haematocephala. Natural Product Research. USA. 20(10): 927-934.

Onyeama, H.P., H.A., Ibekwe, P.Y., Ofemile, A., Peter, M.S., Ahmed, and P.O., Nwagbo. 2012. Screening and Acute Toxicity Studies of Calliandra portoricensis (ERI AGBO In Igbo) Used in the Treatment of Snake Bite in South Eastern Nigeria. Vom Journal of Veterinary Science. 9:17-24.

Orishadipe, A.T., J.I., Okogun, and E., Mishelia. 2010. Gas Chromatography-Mass Spectrometry Analysis of the Hexane Extract of Calliandra portoricensis and Its Antimicrobial Activity. African Journal of Pure and Applied Chemistry. 4(7):131-134.

Tanu I. 2005. Farmakologi dan terapi. Ed ke-4. Jakarta (ID): UI Pr.

Zaid, H., Antonescu, C.N., Randhawa, V.K., and Klip, A. 2008. Insulin Action on Glucose Transporters through Molecular Switches, Tracks and Tethers. Biochem. J. 413: 201-215.

\section{DAFTAR PUSTAKA}

